\title{
8 Internationalization vs Englishization in Italian higher education
}

\author{
Reframing the issue ${ }^{1}$ \\ Amanda C. Murphy and Beatrice Zuaro
}

\begin{abstract}
This chapter investigates the concepts of internationalization/ internazionalizzazione and Englishization/anglicizzazione as used by academics publishing research about Italian higher education in English and Italian. We seek to understand whether internationalization is understood principally as Englishization, and to investigate the resonance of the terms in context. Methodologically, three corpora are analysed within a corpus-assisted discourse studies approach. The findings indicate that internationalization is presented in a neutral light, is not construed exclusively as Englishization, which is used invariably as a negative term indicating an invasive process from which Italian academia needs to defend itself. The research suggests reconsidering the role of English as a way of making Italian academic culture more accessible to international audiences, rather than a threat to its identity.
\end{abstract}

Keywords: internationalization, Englishization, CADS methodology, higher education, Italy

1 This paper was devised and written as an entirely joint project. For the sake of the publication norms in the Italian academic system, Sections 1-3 were written by Beatrice Zuaro, 4-6 by Amanda Murphy, and 7 together.

Wilkinson, Robert, and René Gabriëls (eds), The Englishization of Higher Education in Europe. Amsterdam, Amsterdam University Press 2021 DOI: $10.5117 / 9789463727358$ _CHо8 


\section{Introduction}

The internationalization of Higher Education (HE) in Italy has been a sensitive topic for members of the public tuned into education, due to a clamorous court case won in 2018 by 100 professors from the Politecnico di Milano, one of the most prestigious and respected Italian higher education institutions. The academics took the University to court to challenge a decision taken by the Academic Senate to impose English as the medium of instruction in all MA and PhD courses. This enforced Englishization (anglicizzazione or the more rarely used inglesizzazione in Italian) had enraged some Faculty members, and mainstream newspapers gave space to both voices: the Rector of the University at the time defended the University's position, affirming that 'a graduate who can work in English has five times the opportunities of one who can't' (Cavadini, 2014), ${ }^{2}$ while the authoritative national reference point for the Italian language, Accademia della Crusca, defended the importance of upholding Italian as the national language of education and culture (Maraschio \& De Martino, 2013).

It is no novelty to assert, with Haberland and Mortensen (2012, p. 1), that 'there is more to university internationalization than mere Anglicization', and yet it is undeniable that teaching through English is the fastest way of attracting international students to a country (Tira, 2021). Italy has taken this route decisively: by $2015,100 \%$ of private and $82 \%$ of public Italian HE institutions offered degree programmes in English (Broggini \& Costa, 2017, p. 253), and this unstoppable trend may be one of the reasons why the Politecnico case, well documented and discussed in academic research (Molino \& Campagna, 2014, Pulcini \& Campagna, 2015; Santulli, 2015; among others), continues to be cited by dissenters.

The present paper does not intend to go over this well-rehearsed ground, but rather discusses the issue of internationalization by examining how it has been conceptualized, measured and discussed by the Italian academy. We intend to answer the following questions: How is internationalization in Italian HE conceptualized by academics? Does internationalization coincide with Englishization/anglicizzazione? What resonance does 'Englishization/anglicizzazione' have in Italian academic research? To answer these questions, the paper draws on academic research on internationalization regarding Italian $\mathrm{HE}$, and investigates the contexts in which Englishization or its sister term, anglicizzazione, are used. 


\section{The Italian Context}

In order to properly contextualize the present study, a brief account of the Italian linguistic context, as well as of its policies, seems necessary. In fact, Italy has a complex history which represents the inevitable backdrop to discourses around culture, education, and language. On the one hand, the country is characterized by a long tradition of local academia (the University of Bologna being the first founded in the Western world) and Italian is one of the bigger languages in Europe (Ethnologue, 2019), with significant international relevance in certain domains; on the other hand, the country's long history of divisions has resulted in a unique situation of inner linguistic diversity (Tosi, 2004) which has informed national policies and contributed to a certain sensitivity around the topic of language. While it is estimated that no less than 40 languages were traditionally spoken within Italian territory (Coluzzi, 2009), only Italian currently holds the status of official language of the nation, together with 12 minority languages (Law n. 482/1999).

In the context of the aforementioned inner fragmentation, education is deemed to have played a central role in the unification of the country (De Mauro, 1991). It may thus be unsurprising that Italian is the main language in use at all levels of education. This position of prominence relies, among other factors, on the general interpretation of Art. 9 of the Italian Constitution, which safeguards the 'historical and artistic heritage' of the country, including the national language. Nonetheless, in recent years, as internationalization has been establishing itself as an indicator of quality and prestige in global higher education, the debate around language use has been rekindled. As mentioned in the introduction, the strategy of Italian institutions to increase internationalization seems to have largely revolved around the implementation of English-medium degree programmes. Nonetheless, initial available data painted the picture of a country that was 'slow to internationalize its universities' (Costa \& Coleman, 2013, p. 7; see also Wächter \& Maiworm, 2008, 2014). This trend appears to be confirmed by recent research that found the English-medium instruction (EMI) offer to be on a slow increase (Costa \& Mariotti, 2020). A possible reason for this is the overall moderate proficiency of the English language in Italy: indeed, Italy is one of the few countries in Europe where the competences of the local student population in EMI courses appear to be lower than that of foreign students (Clark, 2018; Wächter \& Maiworm, 2014). 
Despite the challenges, there are signs that EMI courses appeal to different stakeholders, for different reasons, including improvement of the institutional profile, better prospects on the job market for students and even aspirations of language improvement (Ackerley et al., 2017; Clark, 2018; Costa, 2017; Costa \& Coleman, 2013; Costa \& Mariotti, 2017; Guarda \& Helm, 2017). However, the clash of needs, motivations, and expectations has in some instances caused much discussion around higher education policies.

Returning to the example of the Milan litigation mentioned in the introduction, it is important to note that the resistance encountered was not towards the idea of any teaching occurring in a foreign language (in this case, English). In fact, as established by the Ministerial Decree 270/2004, the learning of a foreign language is a qualifying educational objective across disciplines in Italian universities. Rather, opposition was made to the exclusive use of a foreign language as the medium of instruction. The verdict to the court case reaffirmed this: the resolution of the Polytechnic was seen as explicitly contradicting Art. 9 of the Constitution and therefore invalidated (see also Pulcini \& Campagna, 2015; Santulli, 2015). Additionally, it should be noted that, given the rather modest command of the language in this country, implementing courses exclusively via English is seen as having the potential to curtail access to education. This scenario can be especially striking vis-à-vis a cultural environment that has traditionally advocated for accessible education, even at higher education level, via free attendance of lectures at public universities (Royal Decree 1592/1933). ${ }^{3}$

Thus, it would be an oversimplification to read these events as a manifestation of resistance to English in HE tout court. As mentioned, there is evidence in the literature to show favorable approaches in Italian academy to the use of English as the lingua franca. The 'bunker attitude' (Baker, 1992) that often finds particular expression in the media may be but one nuance of a multilayered discussion. To fully appreciate the views of different stakeholders in the internationalization debate, we argue for the need to clarify the terms of this discussion. The contribution of the present article to that end is an investigation of how the ideas of 'internationalization' and 'Englishization' are conceptualized and used in academic research about Italian $\mathrm{HE}$.

3 According to the mentioned Decree, lectures are to be considered public, thus anyone is free to attend them, regardless of whether they are enrolled in a programme or not. 


\section{Review of Literature}

Before moving to the details of the present study, we present an overview of how 'internationalization' and 'Englishization' are understood and discussed in the literature.

Since the so-called 'invention' of internationalization as an element of prestige for higher education institutes (HEIs) (Brandenburg \& de Wit, 2011, p. 15), stakeholders in various capacities have contributed to the codification of the internationalization paradigm. Nonetheless, conceptually the idea of internationalization remains somewhat broad, one oft-cited example being the 'working' definition by De Wit et al. (2015, p. 29), whereby internationalization means:

Integrating an international, intercultural or global dimension into the purpose, functions and delivery of post-secondary education, in order to enhance the quality of education and research for all students and staff, and to make a meaningful contribution to society.

By contrast, more recently Hawawini (2016) stressed the need for a definition which, while remaining applicable to a variety of contexts, places emphasis on the beneficial outcomes of the process, clarifying their twofold nature. In fact, if, on the one hand, institutions benefit from becoming a part of the global knowledge construction process, on the other hand, it is the institutions themselves that contribute to this body of knowledge and to its increase. Thus, Hawawini came to the following formulation (2016, p. 5):

Internationalization is an ongoing process of change whose objective is to integrate the institution and its key stakeholders (its students and faculty) into the emerging global knowledge economy.

If defining internationalization theoretically can prove challenging, the difficulty is heightened when one attempts to pin it down into categories that can be measured. The use of language, for example, can be a difficult indicator: while a shared lingua franca seems an effective way of enacting internationalization, its uniform use can raise issues of 'globalization' (Bull, 2012) and 'linguistic hegemony' (Ives, 2006). Given its strengthened position as the de facto lingua franca of academia (Cots et al., 2012), in the last few decades English has thus found itself at the centre of the debate.

At least in some circles, the equation of 'doing things in English' and internationalization has appeared to be consolidated (e.g., Coleman, 2006; 
Cots et al., 2014; Galloway et al., 2020). The use of English as the default language for international courses is a comfortable practice for institutions, in that it merely consolidates what is already perceived to be the status quo (on the 'self-perpetuating' dynamic of the dominance of English, see Lanvers \& Hultgren, 2018a; see also the 'Catherine wheel' described by Earls, 2013). This 'ever-growing use of English' (Lanvers \& Hultgren, 2018a, p. 1) is often addressed in the literature as 'Englishization', with a shift from the original meaning of the term, traditionally used to indicate linguistic adaptation towards English (Lanvers \& Hultgren, 2018a, drawing on McArthur, 1992).

In previous research, the phenomenon of Englishization has been paired up with various types of complications. Many have raised pedagogical concerns (e.g., Aizawa \& McKinley, 2020; Kaur, 2020; Klaassen, 2001; Wang, 2020). Airey and Linder (2007), in particular, showed that not only there are differences in the way students experience lectures in different languages, but also that they appear to be unaware of such differences, which has important pedagogical implications. It has also been reported that, considering the differences in practices and disciplinary literacy goals among disciplines, the idea of a possible uniform use of language is simplistic and fallacious (e.g., Kuteeva \& Airey, 2014). Ethical implications for access to learning and research have also been reported (e.g., Lanvers \& Hultgren, 2018a; Lueg, 2018), especially for contexts where English has made fewer profound inroads in society (e.g., Kuwamura, 2018; Romaine, 2015; Tsuneyoshi, 2005). Additionally, there are indications in the research to show that students from higher classes are more likely to be socialized into reaping the benefits of an English-medium education, perpetrating mechanisms of elitism and social inequality (Lueg \& Lueg, 2015). In previous research Englishization has also been linked to preoccupations of domain loss, diglossia, and general impact on the international dimension of other languages (e.g., Cots et al., 2012; Cots et al., 2014; Earls, 2013; Phillipson, 2006).

As a result of these considerations, it could be argued that, far from simply describing the presence of English in academic environments (cf. Lanvers \& Hultgren, 2018b), the term Englishization carries negative, albeit not yet precisely codified, connotations.

In this chapter we posit that although much research dealing with internationalization inevitably examines it in connection to Englishization, the two phenomena are associated with different discourses, one of which is more dominant. We look specifically at the context of Italian HE to show that, while much research on the country is indeed conducted under the umbrella of English-medium instruction (e.g., Broggini \& Costa, 2017; Costa, 2017; Costa \& Coleman, 2013; Costa \& Murphy, 2018; Doiz et al., 2020; Guarda 
\& Helm, 2017; Murphy \& Costa, 2018; Pulcini \& Campagna, 2015), above all by linguists, there is also a significant amount of research which, conducted within various disciplines, testifies to the multiple manifestations and interpretations of internationalization in the system. We present the details of our dataset and analysis in the next section.

\section{Methodology}

In order to answer the question of how internationalization is understood and researched by Italian academics, and whether it is construed as Englishization, we have adopted a corpus-assisted discourse studies (CADS) approach, enucleated by Partington (2004a) and clearly laid out in Partington et al. (2013). The use of corpora - large quantities of computerized text - for analysing language, language functions, and ideas was pioneered in Europe by John Sinclair (see, for example, Corpus, Concordance, Collocation, 1991). One of the major insights emerging from his work was, as Thompson and Hunston (2006, pp. 11-12) concisely point out, that meanings are not located in single words, but in 'units of meaning' (Sinclair, 1996); consequently, discourse can thus be described and investigated as a series of semi-fixed phrases. Meaning is created also by the regular phraseologies and collocations that frequently occur with certain words. Another important concept which is relevant to the present study is that of semantic prosody: this has been interpreted either as the property of a word (Partington, 2004b), typically indicating a 'positive or negative attitudinal meaning', which is also gradable (Hunston, 2007, p. 250), or as a property discernible through the surrounding discourse.

Corpus linguistics is typically quantitative: if a pattern of words recurs across different texts, then it is significant, both in terms of observing what is said, and in terms of predicting what could be said. It can also be described as an inductive methodology, in that from a series of repeated instances in text, it infers a general law or principle (Partington et al., 2013, p. 8); accumulating evidence of a phenomenon is also a way into deeper knowledge of that phenomenon. What the CADS approach adds to 'pure' corpus linguistics is the combination of observations deriving from a corpus with knowledge from other sources. Methodologically, this can add a qualitative, even sociological slant, which examines the extra-textual contexts and the society in which they are embedded. It also explains the adoption of reference works such as dictionaries and encyclopaedias for assistance in interpreting the findings in a corpus of texts and understanding how 
the meanings of words can change. 'The aim of the CADS approach is the uncovering [...] of what we might call non-obvious meaning, that is, meaning which might not be readily available to naked-eye perusal' (Partington et al., 2013, p. 11).

To this end, a number of corpora were compiled to provide appropriate data for the research questions. Since the research specifically regards academics in higher education, it was decided to examine the text typologies which represent them most, that is, research articles and book chapters. These constitute the prime research outputs for most academics in the 21st century: they reflect systematic research and considered thought more than other text types, such as newspaper articles, for example. While an issue as topical as internationalization may also create waves in the print and online press, newsworthiness is a prime concern for the press, rather than depth of thought. The academic article is a genre in which evidence-based discourse has been distilled, discussions and conclusions are pondered rather than sensational, and where there is a guaranteed audience of a similar type to the writer. Research articles and book chapters have also normally gone through a peer review quality assurance process.

Two corpora were built following objective criteria. The first was compiled by means of the English search words 'internationalis/zation', 'higher education' and 'Italy/ian' using the databases ProQuest, Elsevier Science Direct, Eric, and Google Scholar. Articles in journals and book chapters published in English and reported in these databases were sought over a span of 20 years (1 January 2000 to 31 December 2020) in the disciplinary areas of applied sciences, business, ecology, economics, education, engineering, environmental sciences, international relations, language and literatures, law, political science, psychology, social sciences, social welfare, and social work. The search words had to appear more than once and not be present only in the bibliography of the articles found. This search produced 69 academic articles $^{4}$ from a cross-section of the above disciplines, which adopt a variety of research methodologies and data types, including annual reports, university strategic plans, and national evaluation reports, for example. A second search was made for articles in English the word 'Englishis/zation', using the same databases and in the same 20-year span; but of the four articles found through this search, two were not about higher education, and the other two were already in the internationalization corpus.

4 Articles and book chapters published in this timespan but not registered in the databases were obviously not included, but the two corpora are representative of academic publications that have international visibility and are available online, some through library subscriptions. 
The total amount of text in English, minus the bibliographies and tables which were removed for the corpus research, is 329,401 running words. The corpus INT-EN thus represents scientific research on the topic of internationalization (and Englishization) written in English.

The same criteria were adopted to build a corpus of academic research about internationalization written in Italian called INT-IT. Accordingly, the search words internazionalizzazione and anglicizzazione referring to Italian higher education were sought through Italian databases and journals. This produced a small amount of data, namely seven articles, amounting to just over 31,000 words. 5

Since the two corpora were constructed according to the same criteria (i.e., through key words in academic journals and books), despite their difference in size, they can be compared with due attention to normalization of numbers. Incidentally, the amount of data available in Italian gives an indication of little attention to the issue of Englishization in published Italian research, despite it attracting a certain amount of attention in the national media; alternatively, it could be an indication that research on the topic is published in English.

Given the small amount of data in Italian, it was decided to build a third corpus containing the articles in a book which is known to be precisely about the topic of internationalization and Englishization, because it contains the academic contributions made in a high-profile debate launched by the national Academy for the Italian language, Accademia della Crusca, after the Politecnico court case. The Academy took a public stance opposing the unilateral use of English in the MA and PhD courses at the Politecnico, and the book illustrates the various positions assumed by academics around the country. The title chosen for the book was clearly provocative: Fuori l'italiano dall'Università? (Exclude Italian from the University?). The size of the corpus is approximately 13,000 words, and it was called the CRUSCA corpus. The difference between this corpus and the INT-IT corpus is that the latter was compiled according to objective criteria, so that it is comparable to the INT-EN corpus. The CRUSCA corpus concentrates specifically on the debate linked to the Politecnico case.

The research followed two steps: the consultation of authoritative dictionaries in both languages for definitions of the words internationalization, ${ }^{6}$ Englishization, and anglicizzazione, and the

5 Many articles were found about the internationalization of companies, but not about higher education.

6 The search for words ending in -zation used * to gain occurrences also with -sation. 
examination of the words (and derivations from the same stems), in the three corpora. The free software Antconc 3.5.9 (Anthony, 2020) was used to examine the words in context, their collocates, and repeated clusters of words in which they occur.

Section 5 presents the definitions of the words, while subsections $5 \cdot 1-5 \cdot 3$ present the findings from the three corpora, with initial comments on the textual examples. The findings are discussed in greater detail in section 6 , while conclusions are drawn in section 7 .

\section{Definitions and Findings}

In the Oxford English Dictionary $(O E D)$, an acknowledged authoritative source for the English language, the first thing to note is that 'internationalization' is a general process, not associated necessarily with education, and is defined: 'The action or process of making something international in character, composition, or scope.' 'Englishization', on the other hand, does not exist as a lemma in the dictionary; the closest word is 'anglicization', of which 'anglicizzazione' is a cognate, whose definition (updated in 2008) is:

i. The action or process of making something or someone English (or British) in character; an instance of this. Also: the acquisition of English (or British) character or characteristics.

ii. An English form or version (of a word or name); an adaptation into English. Typically describing a word formed from the pronunciation or spelling of a foreign term rather than by translation of its meaning.

We note in passing that the dictionary equates 'Englishness' with 'Britishness', a contestable feature which seems dated in the present era where regional and national identity is of increasing importance. More relevantly, the division of meaning into two areas, one relevant to 'character, characteristics', the other to 'words or names' is notable. The definition is neutral and indicates no attitude towards this process. ${ }^{7}$

7 For the purpose of comparison, more recently compiled and corpus-based dictionaries, such as the Cambridge Advanced Learner's Dictionary (CALD), and the COBUILD dictionary, were also consulted, but they too lack the word 'Englishization'; the verb 'anglicize' is defined in CALD as 'to make or become English in sound, appearance or character'. The added specification of 'sound' is similar to the second meaning listed in the $O E D$. 
As regards Italian dictionaries, one of renowned authority is the Treccani, and the definition of the Italian equivalent anglicizzare is as follows:

Rendere inglese, adattare agli usi, ai costumi, alla cultura inglesi: $a$. un popolo, una nazione; con riferimento alla lingua, accogliere parole o costrutti della lingua inglese (to make English, adapt to English customs, uses, culture: to Englishize a people, a nation; with reference to language, to incorporate words or constructions from English).

The definition is shared by the verb inglesizzare. We note there is no hint of Britain or British culture.

\subsection{Findings from the INT_EN corpus: Internationalization in Italian Higher Education}

The compilation of the INT_EN corpus revealed first of all that the discourse about internationalization in Italy is distributed across a wide variety of disciplinary areas (see Table 8.1). These range from the more classic fields, like education (also higher education, bilingual education) and language and linguistics, with education occupying half the corpus, to the disciplines within the social sciences, such as politics, sociology, policies and language policy, economics, management, planning, entrepreneurship, informatics, statistics, and technology transfer. There is one exception, which is an article from engineering.

Table 8.1 Disciplinary areas in the INT corpus

\begin{tabular}{lr}
\hline Education (Higher, Bilingual) & 31 \\
Economics, Management, Planning, Entrepreneurship & 18 \\
Politics and Policies (Language), Sociology & 11 \\
Informatics, Statistics and Technology Transfer & 6 \\
Language and Linguistics & 2 \\
Engineering & 1 \\
\hline Total & $\mathbf{6 9}$ \\
\hline
\end{tabular}

The frequency with which the concept is named, also counting the various forms of the verb 'internationali*e (*s, *ed, *ing), is 1.4 per 1,00o words. The strongest lexical collocates ${ }^{8}$ of internationali*ation in this corpus are

8 Collocates were calculated via AntConc (Anthony, 2020) using the T-score function, which also takes into account frequency of occurrence. 
university, education, and academic, which are distributed fairly evenly across the corpus. These collocates merely situate internationalization, in the academy, without adding anything significant about the understanding of the concept. Other collocates, however, indicate examples of a less conventional and more specific interpretation. These are spin-offs, co-authorship, and entrepreneurship. Examples 1-3 illustrate these collocates in context.

1) Our approach differs from existing literature since it explores the coauthorship network to measure internationalization across institutions. In fact, we build a network based on co-authorships and we use it to measure internationalization of Italian Universities.

2) the degree of internationalization of academic spinoffs can be a consequence of the presence of a highly international team due to the international propensity of the parent university.

3) Future studies can address the role of entrepreneurial teams in the internationalization of ventures originating from universities and research institutes.

In these and other occurrences of the collocates, there is no indication of positive or negative semantic prosody. They point to the study of the enactment of internationalization through unconventional measures. There are many other collocates of the term internationalization, but none with very high scores that indicate a prominent theme that dominates the discourse. Apart from co-authorships, academic spinoffs, and entrepreneurship, other ways of interpreting and measuring internationalization that are found in the co-text of 'internationalization' emerge as:

a the percentage of international staff compared to total staff;

b cooperation with departments from other countries for joint programmes and double degrees;

c establishment of branches of universities in other countries;

d partnerships with international institutions and multinational firms;

e virtual educational programmes delivered in other countries;

f the influence of Rectors with international mobility on the development of networks and collaborations;

$\mathrm{g}$ Italian student representation in international political forums and policy-making bodies.

By contrast, the word Englishization appears only twice in the whole corpus, in journals from the areas of education and language policy, where it is 
used to mean 'teaching only through English'. Examples 4 and 5 illustrate these two occurrences:

4) it seems impossible to separate the Bologna Process from internationalisation, and internationalisation from the Englishisation of Higher Education: to that extent, the Bologna Process has indeed undermined the EU's goal of multilingualism.

5) The latest studies in the field of English as a corporate language demonstrate that adopting a global language policy is not easy. It is a radical choice. The benefits of 'Englishisation' (as Hiroshi Mikitani calls it, the CEO of Rakuten, Japan's largest online marketplace, who decided in 2010 that English would be the company's official language for business) are significant, but only a few companies have systematically implemented an English-language policy with sustained results.

And here arises a question: Is the university a company? Is its mission the same as that of an international or multinational corporation?

Obviously not.

The INT-EN corpus, which reflects research on internationalization in Italian Higher Education published internationally, shows no dominant interpretation of the concept, and no particular trend of positive or negative semantic prosody, as well as very limited reference to Englishization. It shows an understanding of the variegated ways in which internationalization can be enacted and an overall neutral stance.

\subsection{Findings from the Italian corpus on Internationalization in Italian Higher Education (INT-IT)}

The Italian corpus contains 7 articles written for an Italian audience, taken from four disciplinary areas, as illustrated in Table 8.2.

\section{Table 8.2 Disciplinary areas included in the IT corpus}

\begin{tabular}{lr} 
Language and Linguistics & 3 \\
Social Psychology & 1 \\
Public Law & 1 \\
Education & 2 \\
Total & 7 \\
\hline
\end{tabular}


The word 'internazionalizzazione' occurs 2.7 times per 1,00o words and is distributed throughout all the articles in the corpus. The noun has three lexical collocates: i) 'casa' (home), which occurs in the expression 'internazionalizzazione a casa' (internationalisation at home); ii) 'discorsi' (discourse about) in the expression 'discorsi sull'internazionalizzazione', which is used exclusively in one article contesting the common association of internationalization with mobility and arguing for 'internationalization at home', and iii) 'atenei' (universities), used exclusively in one article that reflects on the consequences of the legal case at the Politecnico di Milan, particularly on courses in foreign languages. Similarly to the results of the investigation into INT-EN, the first collocates do not indicate an attitude towards the phenomenon of internationalization, but specify its context (universities), or the type of internationalization envisaged (i.e., at home).

The one article where 'atenei/universities' is a collocate of internationalization concludes with the following recommendations: 'ben venga l'internazionalizzazione dei nostri Atenei' ('the internationalization of our universities is more than welcome') as long as the following three conditions are met: resistance to intellectual subservience to the English-speaking world, resistance to cultural subjection to the same world, and the search for alternative ways of internationalizing. This example shows that although the collocate itself is not negative the surrounding text reveals a defensive attitude summed up as 'resistance', indicating that the process can only be considered positive if it does not imply subservience to the English language or culture of the English-speaking world.

The word anglicizzazione occurs 0.2 times per 1,000 words and is distributed over 3 articles ( $42 \%$ of the corpus), rather unevenly. It is invariably used in negative contexts: in example 6, we see anglicizzazione glossed as 'killer language', whereas in the article where it occurs most (6 times), the word is used exclusively in the sense of 'incorporating words or constructions from English' which is seen as a negative process. These are illustrated in examples 6 and 7 :

6) Il fenomeno dell'English as a Medium of Instruction (EMI) nel suo complesso ha portato molti a parlare di anglicizzazione delle università, o addirittura di «killer language» (Coleman, 2006) e «pandemic English» (Phillipson, 2009). (The phenomenon of EMI as a whole has led many to speak about the Englishization of universities, or even of a 'killer language' or 'pandemic English'.) 
7) Per fermare, o almeno frenare, una tale anglicizzazione della lingua italiana, e similmente delle altre lingue, e per renderle la sua purezza, non servirebbero forse delle contromisure come quelle dei francesi? (To stop, or at least slow down, such an anglicization of the Italian language, and in the same way of other languages, and to restore her purity, would we not need some kind of countermeasures like those adopted by the French?)

Comment: Anglicization is seen as a pernicious process that needs to be stopped or slowed down.

In the INT-IT corpus, internationalization is discussed mostly in terms of internationalization at home, which in fact does not need to take place in English, but which can mean internationalizing the curriculum, for example (Leask, 2015). Anglicizzazione is mentioned solely in connection with the negative effect on other languages, which leads to monolingualism and subservience to Anglophone culture.

\subsection{Findings from the CRUSCA corpus}

The articles in the CRUSCA corpus comprise all the contributions to the debate on the use of English as a vehicle of instruction at university, promoted by the Accademia della Crusca in 2012. This corpus is expected to produced negative examples about Englishization, given the heated debate it represents.

The search for 'internazionalizz* produced various forms of the verb 'internazionalizzare' as well as the noun, and 'anglicizzazione', and more various related words, including anglicismo (anglicism), anglicizzat* (anglicized), anglicizzante (Englishizing - adj), anglitaliano (Italish), than in the INT-IT corpus.

Internazionalizzazione or related words occur 5.5 times per 1,000 words, much more than anglicizzazione which occurs 1.8 times per 1,000 words. The top lexical collocates of internazionalizz* are: università (university) and sistema (system), which as in the other two corpora both indicate the context of use, while not revealing anything about how it is conceptualized or positive or negative semantic prosody: internazionalizzazione delle università (internationalization of universities), internazionalizzazione del sistema universitario italiano (internationalization of the Italian university system). Anglicizzazione proved to be more fertile ground in terms of discerning positive or negative semantic prosody, and Table 8.3 illustrates the numbers 
of occurrences of the word and its derivates, and the classification into positive or negative contexts of use.

Table 8.3 Occurrences of words beginning with angl* and their positive or negative contexts in the Crusca corpus

\begin{tabular}{lccc}
\hline & $\begin{array}{c}\text { TOTAL } \\
\text { OCCURRENCES }\end{array}$ & $\begin{array}{c}\text { POSITIVE or } \\
\text { NEUTRAL CONTEXT }\end{array}$ & $\begin{array}{c}\text { NEGATIVE } \\
\text { CONTEXT }\end{array}$ \\
\hline $\begin{array}{l}\text { Anglicizzazione } \\
\text { Englishization } \\
\text { anglismi/o } \\
\text { anglicismi/o }\end{array}$ & $\mathbf{8}$ & 2 & 6 \\
$\begin{array}{l}\text { Anglicisms } \\
\text { anglicizzata/i: }\end{array}$ & $\mathbf{1}$ & 1 & 3 \\
$\begin{array}{l}\text { Anglicized } \\
\text { anglico/ anglicus }\end{array}$ & 3 & 1 & 3 \\
$\begin{array}{l}\text { English } \\
\text { anglicizzante/i } \\
\text { Sounding English } \\
\begin{array}{l}\text { Anglitaliano A language mixture } \\
\text { of English and Italian-Englian }\end{array}\end{array}$ & 3 & 1 & 2 \\
\hline TOTAL & 3 & & 1 \\
\hline
\end{tabular}

Six examples of the co-texts surrounding the words are reported, translated, and briefly commented on here. In examples 8-13, anglicizzazione has a negative semantic prosody, judging from the surrounding co-text. In example 13, the process is seen from two points of view and appears to be neutral.

8) Che francese e spagnolo appartengano a questa categoria, non c'è alcun dubbio. Basta pensare alla tenacia con cui hanno frenato l'anglicizzazione della terminologia del computer. (There's no doubt that French and Spanish belong to this category of 'languages of culture'. It's enough to think of the tenacity with which they put a brake on the anglicization of computer terminology.)

Comment: the use of 'tenacity' and the verb 'brake' (frenare) would indicate that the anglicization process is something negative that has doggedly been stopped.

9) Diversa, naturalmente, è la situazione nelle aree umanistica e giuridica, dove è inaccettabile oltre che un po' ridicolo il principio che le 
pubblicazioni in inglese (p. es. nel settore dell'italianistica!) valgano più di quelle in italiano; ma dove non vedo alcuna minaccia di anglicizzazione dell'insegnamento. (The situation in courses in the areas of Humanities and Law is quite different, where it is unacceptable as well as rather ridiculous that publications in English (e.g. in the sector of Italian studies) should be worth more than those in Italian; but I see no threat of anglicization of teaching)

Comment: the fact that anglicization is seen as a threat confers a negative aura to the process.

10) è molto significativo che anche la Germania, la quale ha affrontato questi problemi prima di noi [...] ed è quindi più avanti nel processo di anglicizzazione, stia ripensando le sue scelte. (it is extremely significant that even Germany, who faced these problems before we did [...] and who is therefore further on than us in the process of anglicization, is rethinking the choices that were made.)

Comment: a country that is more anglicized than Italy is reconsidering the choices it made - this implies that the choices were not good and that therefore anglicization is not a good thing; the mention of 'problems' also confers a problematic aura on the process of anglicization.

11) Ironicamente i nostri avi hanno resistito l'anglicizzazione per $15^{0}$ anni, difendendo l'italiano come acroletto [...] no ai primi decenni del Novecento, ma oggi dobbiamo ammettere che per noi il cambiamento è stato un vantaggio. (Ironically, our ancestors resisted anglicization for 150 years, defending Italian as acrolect... but today we must admit that the change brought us advantages.)

Comment: the use of 'resist' implies that anglicization was not considered a good process, and Italian needed to be defended from it. The coordinated clause introduced by 'but' resets the balance, implying that this point of view is no longer shared, thus neutralizing the negativity.

12) Non si può ignorare che l'applicazione totalitaria dell'anglicizzazione dei corsi anzidetti creerà una netta preselezione sociale e ambientale dei fruitori. (It cannot be ignored that the totalitarian application of the anglicization of the prementioned courses will bring about a precise social and environmental pre-selection of the students.) 
Comment: the adoption of the adjective 'totalitarian' could be a neutral choice, if the adjective is being used just to mean 'total', but its connotations are inevitably negative; moreover the consequences of the anglicization process - that students are preselected on the basis of economic and social grounds - creates negative backlash to the anglicization process and the sentence as a whole.

13) Perché è apparso immediatamente chiaro il rischio da evitare: quello che su un tema tanto delicato e in un momento significativo di svolta (che parte dall'università ma non si limita certo a essa) si determinasse una contrapposizione netta, quasi manichea, tra fautori e oppositori dell'anglicizzazione, tra chi cioè vede nella scelta dell'inglese come lingua veicolare dell'insegnamento il modo migliore, più semplice ed economico per i nostri atenei di aprirsi al mondo e chi invece difende ad oltranza la lingua italiana, appellandosi alla forza e all'autorevolezza della tradizione nazionale. Inglese contro italiano, insomma, in una visione semplificante e fuorviante. (It became immediately clear that a riskneeded to be avoided: that of creating - on a rather delicate issue, which had emerged at a significant turning point (which starts in university but would go beyond it), a distinct, almost Manichean contraposition between the advocates and opponents of anglicization, between those who see the choice of English as a vehicular teaching language as the best, simplest and most economical way for our universities to open up to the world and those who defend Italian all-out, invoking the strength and authority of national tradition. English against Italian, in other words, in a simplistic and misleading way.)

Comment: anglicization is construed as a process that can be seen as a fast, simple, and economic way of opening universities up to the world, or as bad thing because it attacks national tradition. A neutral use of the word.

\section{Discussion}

The findings in the corpus of articles in English (INT-EN) scarcely mention or discuss the concept of Englishization with regards to internationalization, with the word occurring only twice in publications from the areas of language and linguistics in a corpus of 69 articles. Both instances of the search word Englishization occur in negative contexts, implying that the process undermines plurilingual competences and that universities 
should not apply monolingual policies that may characterize companies. On the other hand, the discussions of internationalization in this corpus are embedded in a wide range of disciplinary areas, and their attention is focused on various enactments of internationalization, such as co-authored publications, international, academic spin-offs, entrepreneurship, the presence of international staff, virtual education, and so on. Neither Englishization nor simply English appear as lexical collocates of the noun internationalization, nor do the classic indicators of international mobility and the presence of international students in a university. This is the corpus where debate does not appear to be polarized, where discussion of the topics is broad ranging, and touches on innovative measures of internationalization, such as academic spin-offs and entrepreneurship. The research in this corpus, reported in English, is directed at an international audience, which may influence the more nuanced and multi-layered attitude towards the phenomenon and the lack of a clear polarization around the Englishization process.

In the small Italian corpus on internationalization, INT-IT, the research is produced by scholars from various disciplines, and internationalization is mentioned generally in the form of internationalization at home, with one article encouraging resistance to cultural subservience to the English-speaking world. 'Anglicizzazione' is mentioned in fewer than half the articles in the corpus, and is seen as a process requiring resistance, since incorporating English words into the Italian language attacks its purity, and the adoption of English generally encourages an exclusive, monolingual, and monocultural outlook; a few examples show a balanced attitude towards the process, recognizing that there are good reasons for publishing in English internationally. The third corpus, composed entirely of contributions provoked by the Polytechnic court case, understandably shows the highest frequency of both 'internazionalizzazione' and 'anglicizzazione'; while the first term is used without any noticeable positive or negative connotations, the second demonstrates a predominantly negative semantic prosody, describing the process as a threat needing to be braked or resisted, and a path taken and subsequently regretted by some countries. There is, however, admission of the fact that Englishization is a simple and fast way of opening universities up to the world. Both the INT-IT and CRUSCA corpora are directed at predominantly Italian audiences; the former was compiled through objective criteria and could in theory be for an international (Italianspeaking) audience, but the prosody of anglicizzazione is predominantly negative, as in the CRUSCA corpus, which fulfils expectations of negativity, given the circumstances it represents. 
Overall, the negative connotations of Englishization in these corpora are largely consistent with what has been reported in previous research, which frames it as a de facto monolingual and hegemonic process (e.g., Cots et al., 2012; Cots et al., 2014; Earls, 2013; Ives, 2006; Lanvers \& Hultgren, 2018a, b; Phillipson, 2006). The Italian understanding of internationalization as a wide-ranging phenomenon is also in line with the general paradigm: the focus on its enactments and on the various stakeholders here identified is also a feature of current definitions of internationalization (see De Wit et al., 2015; Hawawini, 2016). Whether, by rejecting Englishization's monolingual model, internationalization inherently comes to signify plurilingualism is not clearly established by the present analysis (and, indeed, see Kuteeva, 2020, for a discussion of 'wishful multilingualism'). Nonetheless, the differences in how Englishization and internationalization are construed in these corpora appear prominently and represent the main finding of the present study.

\section{Conclusions}

The present study aimed to investigate how 'internationalization' and 'Englishization' are conceptualized in research about Italian HE. To that end, academic publications both in Italian and English were analysed with a focus on the use of this terminology, its context, and its nuances. In this section, we provide answers to our original research questions to draw the conclusions of the study.

The investigations conducted here show that, across disciplines, the term 'internationalization' has no prevailing attitudinal undertones and, while its use appears firmly nestled in the context of education, its interpretation remains broad and connected to several indicators. On the contrary, 'Englishization' was shown to be associated with consistently negative semantic prosody, in fact never occurring in a positive light in any of the corpora. In line with what previous research brought to light (see section 3), when Englishization/ anglicization/anglicizzazione does appear in these corpora, it carries connotations of threat, problem, or injustice. This shows that internationalization and Englishization do not coincide in either meaning or use. Furthermore, their distribution was clearly different in the corpora, indicating that, most frequently, internationalization is not discussed in direct association with Englishization.

Overall, we conclude that, in light of its connotations, Englishization is not perceived as a desirable phenomenon in this context. This perception appears to have two nuances (in line with what originally noted for dictionary entries in both languages) investing both language and culture. Nonetheless, we remark that this stance is no indication of attitudes around internationalization itself, 
given the ascertained distinction between the two phenomena. It should be noted, however, that much like the simple introduction of English in education systems is not a reliable indicator of internationalization, similarly not all use of English should be connected to processes of Englishization and its negative connotations. Internationalization achieved through the medium of English can represent a bridge to other cultures and a way of making Italian academic culture more accessible to international audiences, rather than a threat to its identity (Maggioni \& Murphy, 2018). In the future, further research could productively focus on identifying ways in which this accessibility could be enhanced. Fortunately, as our results seem to indicate, internationalization is clearly understood by academics to be much more than Englishization, which is a trend that will hopefully become prevalent.

\section{Acknowledgement}

This chapter gained enormously from the peer-review process. The authors wish to thank the anonymous reviewers for engaging deeply and constructively with the first version of the chapter.

\section{References}

Ackerley, K., Guarda, M., \& Helm, F. (2017). Sharing perspectives on English-medium instruction. Peter Lang.

Airey, J., \& Linder, C. (2007). Disciplinary learning in a second language: A case study from university physics. In R. Wilkinson \& V. Zegers (Eds.), Researching content and language integration in higher education (pp. 161-171). Maastricht University Language Centre.

Aizawa, I., \& McKinley J. (2020). EMI challenges in Japan's internationalization of higher education. In H. Bowles \& A. C. Murphy (Eds.), English-medium instruction and the internationalization of universities (pp. 27-48). Palgrave Macmillan. DOI: 10.1007/978-3-030-47860-5_2

Anthony, L. (2020). AntConc (Version 3.5.9) [Computer Software]. Tokyo, Japan: Waseda University. Available from https://www.laurenceanthony.net/software

Baker, C. (1992). Attitudes and language. Multilingual Matters.

Brandenburg, U., \& de Wit, H. (2011). The end of internationalization. International Higher Education, 62, 15-17.

Broggini, S., \& Costa, F. (2017). A survey of English-medium instruction in Italian higher education. Journal of Immersion \& Content-Based Language Education, $5(2), 238-264$. 
Bull, T. (2012). Against the mainstream: Universities with an alternative language policy. International Journal of the Sociology of Language, 216, 55-73.

Cavadini, F. (2014, 29 July). Corsi in inglese, errore opporsi al TAR [Courses in English, opposing the TAR is a mistake]. Corriere della Sera.

Clark, C. (2018). The case of the non-native English speaker in EMI. Studi e ricerche, $13,563-576$.

Coleman, J. (2006). English-medium instruction in European higher education. Language Teaching, 39(1), 1-14.

Coluzzi, P. (2009). Endangered minority and regional languages ('Dialects'). Modern Italy, 14(1), 39-54.

Costa, F. (2017). English-medium instruction in Italian universities: If we're gonna do it do it right - right? In M. Guarda, F. Helm, \& K. Ackerley (Eds.), Sharing perspectives on English-medium instruction (pp. 77-94). Peter Lang.

Costa, F., \& Coleman, J. (2013). A survey of English-medium instruction in Italian higher education, International Journal of Bilingual Education and Bilingualism, 16(1), 3-19. DOI: 10.1080/13670050.2012.676621

Costa F., \& Mariotti C. (2017). Students' profiles and their reception of Englishmedium instruction in Italian universities, In C. Boggio \& A. Molino (Eds.), English in Italy: Linguistic, educational and professional challenges (pp. 160-181). Franco Angeli.

Costa, F., \& Mariotti C. (2020). EMI students' 'international coexistence' at one Italian university. In H. Bowles \& A. C. Murphy (Eds.), English-medium instruction and the internationalization of universities (pp. 229-258). Palgrave Macmillan. DOI: 10.1007/978-3-030-47860-5_10

Costa, F., \& Murphy, A. C. (2018). Supporting the switch to teaching international classes in tertiary education. In C. M. Coonan, A. Bier, \& E. Ballarin (Eds.), La didattica delle lingue nel nuovo millennio: le sfide dell'internazionalizzazione (pp. 599-613), Edizioni Ca' Foscari - Digital Publishing.

Cots, J. M., Lasagabaster, D., \& Garrett, P. (2012). Multilingual policies and practices of universities in three bilingual regions in Europe. International Journal of the Sociology of Language, 216, 7-32.

Cots, J. M., Llurda, E., \& Garrett, P. (2014). Language policies and practices in the internationalisation of higher education on the European margins: An introduction. Journal of Multilingual and Multicultural Development, 35(4), 311-317. DOI: 10.1080/01434632.2013.874430

De Mauro, T. (1991). Storia linguistica dell'Italia unita [Linguistic history of unified Italy]. Editori Laterza.

De Wit, H., Hunter, F., Howard, L., \& Egron-Polak, E. (2015). Internationalisation of higher education. European Parliament, Committee on Culture and 
Education. Retrieved from http://www. europarl.europa.eu/RegData/etudes/ STUD/2015/540370/IPOL_STU\%282015\%29540370_EN.pdf

Doiz, A., Costa, F., Lasagabaster, D., \& Mariotti, C. (2020). Linguistic demands and language assistance in EMI courses: What is the stance of Italian and Spanish undergraduates? Lingue e Linguaggio, 33, 69-85.

Earls, C. W. (2013). Setting the Catherine wheel in motion. Language Problems and Language Planning, 37(2), 125-150. DOI: 10.1075/lplp.37.2.02ear

Eberhard, D. M., Simons, G. F., \& Fennig, C. D. (Eds.) (2021). Ethnologue: Languages of the world. Twenty-fourth edition. SIL International. Retrieved ${ }_{15}$ February 2021 from http://www.ethnologue.com.ezp.sub.su.se.

Galloway, N., Numajiri, T., \& Rees, N. (2020). The 'internationalisation', or 'Englishisation', of higher education in East Asia. Higher Education, 8o(3), 395-414. DOI: 10.1007/s10734-019-00486-1

Guarda, M., \& Helm, F. (2017). 'I have discovered new teaching pathways': The link between language shift and teaching practice. International Journal of Bilingual Education and Bilingualism, 20(7), 897-913. DOI: 10.1080/13670050.2015.1125848

Haberland, H., \& Mortensen, J. (2012). Language variety, language hierarchy and language choice in the international university. International Journal of the Sociology of Language, 2, 1-6. DOI: 10.1515/ijsl-2012-0036

Hawawini, G. (2016). The internationalization of higher education and business schools. Springer.

Hunston, S. (2007). Semantic Prosody Revisited. International Journal of Corpus Linguistics, 12(2), 249-268.

Ives, P. (2006). 'Global English': Linguistic imperialism or practical lingua franca? Studies in Language and Capitalism, 1, 121-141.

Kaur, J. (2020). Using English for interaction in the EMI classroom: Experiences and challenges in a Malaysian public university. In H. Bowles \& A. C. Murphy (Eds.), English-medium instruction and the internationalization of universities (pp. 129-154). Palgrave Macmillan. DOI: 10.1007/978-3-030-47860-5_6

Klaassen, R. G. (2001). The international university curriculum: Challenges in English-medium engineering education [Doctoral dissertation, Technische Universiteit Delft].

Kuteeva, M. (2020). If not English, then what? Unpacking language hierarchies at university. In M. Kuteeva, K. Kaufhold, N. Hynninen (Eds.), Language perceptions and practices in multilingual universities (pp. 27-55). Palgrave Macmillan. DOI: 10.1007/978-3-030-38755-6_2

Kuteeva, M., \& Airey, J. (2014). Disciplinary differences in the use of English in higher education: Reflections on recent language policy developments. Higher Education, 67(5), 533-549. DOI: 10.1007/s10734-013-966o-6 
Kuwamura, A. (2018). The future of English-medium instruction in Japan. In A. Bradford \& H. Brown (Eds.), English-medium instruction in Japanese higher education (pp. 265-282). Multilingual Matters.

Lanvers, U., \& Hultgren, A. K. (2018a). The Englishization of European education: Foreword. European Journal of Language Policy, 10(1), 1-11.

Lanvers, U., \& Hultgren, A. K. (2018b). The Englishization of European education Concluding remarks. European Journal of Language Policy, 1o(1), 147-152. DOI: 10.3828/ejlp.2018.7

Law/Legge (1999, 20 December). 15 December 1999, n. 482. Norme in materia di tutela delle minoranze linguistiche storiche. (Italy). Gazzetta Ufficiale, (297). Retrieved 15 February 2021 from https://www.gazzettaufficiale.it/eli/ id/1999/12/20/099G0557/sg

Leask, B. (2015). Internationalizing the curriculum. Routledge.

Lueg, K. (2018). The internationalization of higher education in Europe: A discussion of English as a medium of instruction and its implication. Culture, Practice \& Europeanization, 3(1), 47-67.

Lueg, K., \& Lueg, R. (2015). Why do students choose English as a medium of instruction? A Bourdieusian perspective on the study strategies of non-native English speakers. Academy of Management Learning and Education, 14(1), 5-30. DOI: 10.5465/amle.2013.0009

Maggioni, M. L., \& Murphy, A. C. (2018). La lingua o le lingue inglesi oggi: strumento di egemonia culturale o ponte? [The English language or languages today: a means to cultural hegemony or bridge?] In G. Del Zanna (Ed.), La geopolitica e le lingue (pp. 33-44). Maggioli.

Maraschio, N., \& De Martino, D. (2013). Fuori l'italiano dall'università?: inglese, internazionalizzazione, politica linguistica [Exclude Italian from the University?: English, internationalization, language policy]. Laterza.

McArthur, T. (1992). The Oxford companion to the English language. Oxford University Press.

Ministerial Decree/Decreto Ministeriale (2004, 12 November). 22 October 2004, n. 270. Modifiche al regolamento recante norme concernenti l'autonomia didattica degli atenei, approvato con decreto del Ministro dell'università e della ricerca scientifica e tecnologica 3 novembre 1999, n. 509. (Italy). Gazzetta Ufficiale, (266). Retrieved 15 February 2021 from https://www.gazzettaufficiale.it/eli/ $\mathrm{id} / 2004 / 11 / 12 / 004 \mathrm{Go303} / \mathrm{sg}$

Molino, A., \& Campagna, S. (2014). English-mediated instruction in Italian universities: Conflicting views. Sociolinguistica, 28(1), 155-172. DOI: $10.1515 /$ soci-2014-0013 Murphy, A. C., \& Costa, F. (2018). Language and internationalization of the higher education curriculum. In P. Teixeira \& J. Shin (Eds.), Encyclopedia of 
international higher education systems and institutions (pp. 1961-1964). Springer. DOI: 10.1007/978-94-017-9553-1_223-1

Oxford English Dictionary (2021). Retrieved 15 February 2021 from www.oed.com Partington, A. (2004a). Corpora and discourse. A most congruous beast. In A. Partington, J. Morley, L. Haarman (Eds.), Corpora and Discourse (pp. 11-2o). Peter Lang.

Partington, A. (2004b). 'Utterly content in each other's company': Semantic prosody and semantic preference. International Journal of Corpus Linguistics, 9(1), 131-156.

Partington, A., Duguid, A., \& Taylor, C. (2013). Patterns and meanings in discourse: Theory and practice in corpus-assisted discourse studies (CADS). John Benjamins. Phillipson, R. (2006). English, a cuckoo in the European higher education nest of languages? European Journal of English Studies, 10(1), 13-32.

Pulcini, V., \& Campagna, S. (2015). Internationalisation and the EMI controversy in Italian higher education. In S. Dimova, A. K. Hultgren, \& C. Jensen (Eds.), English-medium instruction in European higher education (pp. 89-114). De Gruyter Mouton.

Romaine, S. (2015). The Pushmi-Pullyu of language policy and political economy. In T. Ricento (Ed.), Language policy and political economy (pp. 252-275). Oxford University Press.

Royal Decree/Decreto Regio (1933, 7 December). 31 August 1933, n. 1592. Approvazione del testo unico delle leggi sull'istruzione superiore. (Italy). Gazzetta Ufficiale, (283), 1-156.

Santulli, F. (2015). English in Italian universities: The language policy of PoliMi from theory to practice. In S. Dimova, A. K. Hultgren, \& C. Jensen (Eds.), Englishmedium instruction in European higher education (pp. 269-9o). De Gruyter Mouton.

Sinclair, J. (1996). The search for units of meaning, Textus, 9(1), 75-106.

Sinclair, J. (1991). Corpus, concordance, collocation. Oxford University Press.

Thompson, G., \& Hunston, S. (2006). System and corpus: Two traditions with a common ground. In G. Thompson \& S. Hunston (Eds.), System and corpus: Exploring connections (pp. 1-14). Equinox Publishing.

Tira, M. (2021). Introductory remarks at 'La formazione linguistica quale veicolo di internazionalizzazione degli atenei italiani' [Language education as a vehicle for the internationalization of Italian universities], Conference held online at Università di Venezia Ca' Foscari, 25-26 February 2021.

Tosi, A. (2004). The language situation in Italy. Current Issues in Language Planning, 5(3), 247-335, DOI: 10.1080/14664200408668259

Treccani (n.d.). Retrieved 15 February 2021 from www.treccani.it/vocabolario

Tsuneyoshi, R. (2005). Internationalization strategies in Japan.Journal of Research in International Education, 4(1), 65-86. 
Wang, Y. (2020). The role of English in higher education internationalisation: Language ideologies on EMI programmes in China. In H. Bowles \& A. C. Murphy (Eds.), English-medium instruction and the internationalization of universities (pp. 103-128). Palgrave Macmillan. DOI: 10.1007/978-3-030-47860-5_5

Wächter, B., \& Maiworm, F. (2008). English-taught programmes in European higher education. The picture in 2007. Lemmens.

Wächter, B., \& Maiworm, F. (2014).English-taught programmes in European higher education: The state of play in 2014. Lemmens.

\section{About the authors}

AmAnda C. MurPhy, PhD is Professor of English language at Università Cattolica del Sacro Cuore, Italy. Her interests include corpus-related analyses of language, English as a medium of instruction and the internationalization of higher education. She is the co-editor (with Hugo Bowles) of English-medium Instruction and the Internationalization of Universities (Palgrave 2020).

BEATrice ZuAro is a PhD candidate at the Department of English of Stockholm University. Her PhD project is an investigation of English-medium Instruction (EMI), specializing in the context of Italian Higher Education. Her main research interests encompass language policy and language ideologies, EMI and academic discourse in general. 